\title{
オリザリンおよびコルヒチン処理によるスノキ属植物における倍数体の作出
}

\author{
津田浩利 ${ }^{1} \cdot$ 小島祥子 ${ }^{2}$ •鉄村环哉 ${ }^{2} \cdot$ 小松春喜 $^{3}$ ・國武久登 ${ }^{2 *}$ \\ 1 宮崎大学大学院農学工学総合研究科 $889-2192$ 宮崎市学園木花台西 \\ 2 宮崎大学農学部 889-2192 宮崎市学園木花台西 \\ 3 東海大学農学部 869-1404 阿蘇郡南阿蘇村河陽
}

\section{Induction of Polyploids in Vaccinium Using Oryzalin and Colchicine Treatments}

\author{
Hirotoshi Tsuda ${ }^{1}$, Shoko Kojima ${ }^{2}$, Takuya Tetsumura ${ }^{2}$, Haruki Komatsu ${ }^{3}$ and Hisato Kunitake ${ }^{2 *}$ \\ ${ }^{1}$ Interdisciplinary Graduate School of Agriculture and Engineering, University of Miyazaki, Miyazaki 889-2192 \\ ${ }^{2}$ Faculty of Agriculture, University of Miyazaki, Miyazaki 889-2192 \\ ${ }^{3}$ School of Agriculture, Tokai University, Kumamoto 869-1404
}

\begin{abstract}
To establish an efficient polyploid induction method, we carried out in vitro chromosome doubling of multiple shoots in some Vaccinium species. Multiple shoots were aseptically treated with two antimitotic agents, oryzalin and colchicine, at different concentrations and times. After these treatments, the shoots were successively cultured on MW medium containing $5 \mathrm{mg} \cdot$ $\mathrm{L}^{-1}$ zeatin. The ploidy levels of growth shoots were evaluated by both flow cytometry and chromosome counting. The frequency of chromosome-doubled plant production depended on the kinds of antimitotic agent, treatment concentrations and times, and species. Among the treatment conditions tested, oryzalin induced more chromosome doubling than colchicine. Four species of chromosome-doubled plants were obtained with $0.005 \% 24$-hour oryzalin treatment at the following frequencies: V. corymbosum 'Berkeley': $23.3 \%$, V. smallii: $5.6 \%$, V. vitis-idaea: $40.0 \%$, V. uliginosum: $57.8 \%$. These results suggest that oryzalin is very effective for polyploid induction of multiple shoots in Vaccinium.
\end{abstract}

Key Words : blueberry, chromosome doubling, flow cytometry, multiple shoot, wild Japanese species

キーワード：ブルーベリー，フローサイトメーター，日本産野生種，染色体倍加，多芽体

\section{緒 言}

現在, 我が国で栽培されているブルーベリ一は, 四倍体 の北部ハイブッシュブルーベリー（Vaccinium corymbosum L.）と南部ハイブッシュブルーベリー（V. corymbosum interspesific hybrid）および六倍体のラビットアイブルーベリー （V. virgatum Aiton）の3 種であり，これらの多くは米国で 育成されたものである。一方，我が国には，ブルーベリー と近縁のスノキ属植物が 14 種または 18 種自生している(北 村・村田, 1971; 山崎, 1989). 岩垣（1984）は, 古くから これら日本産野生種の育種素材としての有望性を指摘して きたが，ブルーベリ一の品種改良にはほとんど利用されな かった（Hiirsalmi, 1988）。ブルーベリ一やその近縁野生種 であるビルベリー（V. myrtillus L.）は，ポリフェノールな どの抗酸化成分を多く含む機能性果実として注目されてい る（Kalt ら，1999）. Yoshizawa ら（2002）は，我が国に自 生するナッハゼ (V. oldhamii Miq.) の果実抽出物のガン細

2011 年 7 月 11 日 受付. 2011 年 9 月 24 日 受理.

* Corresponding author. E-mail: hkuni@cc.miyazaki-u.ac.jp
胞増殖抑制効果を報告して扣り，高木ら（2005）は，ナッ 八ゼ果実がブルーベリ一栽培品種と比較して高い抗酸化能 やポリフェノールを有していることを明らかにして拈り, 日本産野生種の育種への活用が望まれている。近年，小松 ら（2003，2006）は，我が国に自生して果実のポリフェノー ル含量と抗酸化活性が栽培種よりも高いクロマメノキ（ $V$. uliginosum L.) と, 食味に優孔る北部ハイブッシュブルー ベリー 'Bluecrop' との種間交雑を行い, 両親の中間の果 実特性を有する雑種を獲得しており，これらが食味に優れ 機能性に富む新品種育成のための育種母本になり得ると報 告している.

米国では，ブルーベリ一育種の開始以来，様々な近縁野 生種が品種改良に利用されてきた (Chavez・Lyrene, 2009a).

しかしながら，スノキ属に拈いては，三倍体接合体の崩壊 による強いトリプロイドブロックが原因で，二倍体野生種 と四倍体のハイブッシュブルーベリーとの交雑は容易でな い(Sharp・Sherman, 1971)。一方，スノキ属に打ける同倍 数体間の交雑に打いては，稔性を有する樹勢の強い雑種が 多数得られている（Lyrene・Ballington, 1986）. そのため, 二倍体野生種を人為的に染色体倍加することで，四倍体と 
の交雑が容易になると考兄られる (Chavez・Lyrene, 2009b). 実際に, 二倍体の V. elliottii Chapm. を花粉親として四倍体 の南部ハイブッシュブルーベリーと交雑した結果, 受粉 1 花当たりの獲得実生数が 0.01 であったのに対し, コルヒチ ン処理により得られた V. elliottii Chapm. の同質四倍体を花 粉親とした場合では 3.86 であった (Dweikat・Lyrene, 1991).

コルヒチンによる人為的な倍数体作出方法（Blakeslee ・ Avery, 1937）が開発されてから, 様々な有系分裂阻害物質 が染色体倍加に利用されてきた。 ジニトロアニリン系除草 剤であるオリザリン [3,5- ジニトロ -4- (ジプロピルアミノ) ベンゼンスルホンアミド］ $\left(\mathrm{C}_{12} \mathrm{H}_{18} \mathrm{~N}_{4} \mathrm{O}_{6} \mathrm{~S}\right)$ は, 低濃度で多 くの染色体倍加個体が得られること（Väinöolä, 2000），奇 形器官や成育異常の発生が少ないこと（van Tuyl ら，1992） などの理由により, 近年コルヒチンと同様に染色体倍加に 利用されている。実際に，リンゴ (Bouvier ら， 1994），ナ シ（Bouvier ら，2002），バナナ（Van Duren ら，1996）お お よびキンカン（八幡ら，2004）など，多くの果樹でオリザ リンによる染色体倍加が行われている. スノキ属植物に沶 いても，種子 (Chavez・Lyrene, 2009b; Miyashita ら, 2009; Rousi, 1967) や成長点（Dweikat - Lyrene, 1989; Moore ら, 1964）にコルヒチンを処理することにより染色体倍加個体 が作出されているが，これまでにコルヒチン以外の有系分 裂阻害物質の有効性は全く検討されていない，さらに，ス ノキ属植物の染色体倍加個体の誘導率に言及した報告は少 なく，効率的な染色体倍加方法は確立されていない。

そこで本研究では，まず，スノキ属植物に打ける染色体 倍加方法を確立するために, 栽培品種の多芽体由来シュー トをオリザリンとコルヒチンに浸漬処理し, 染色体倍加に 最適な処理濃度と時間を検討した. 次に，栽培品種で確立 した最適条件を用いて，我が国に自生するスノキ属植物 4 種の染色体倍加を試みた。

\section{材料および方法}

\section{1. 栽培品種でのコルヒチンおよびオリザリン処理条件の 検討 (実験 1)}

植物材料として, 北部ハイブッシュブルーベリー ‘Berkeley’を供試した. Tetsumura ら（2008）と山内（佐藤） ら（2012）の方法に従い，発芽直前の腋芽を滅菌した後，2 \%スクロース, $0.8 \%$ 寒天拈よび $5 \mathrm{mg} ・ \mathrm{~L}^{-1}$ zeatin を添加した MW 培地 [MS 培地 (Murashige ・ Skoog, 1962) と WPM 培 地（Wolfe ら，1983）を等量混合] $(\mathrm{pH} 4.8)$ 飞置床し， $25^{\circ} \mathrm{C}$, 24 時間連続照明下 $\left(38 \mu \mathrm{mol} \cdot \mathrm{m}^{-2} \cdot \mathrm{s}^{-1}\right)$ で多芽体を誘導し た. 2 か月ごとに同培地で多芽体を継代培養し, 実験に必要 なシュート数になるまで継代培養を繰り返した。

新たに発生したシュートを約 $40 \mathrm{~mm}$ 長に調製し， $0.2 \mu \mathrm{m}$ のフィルター（ザルトリウス）で滅菌したコルヒチン溶液 またはオリザリン溶液に浸漬した。なお，オリザリン溶液 は Dimethyl sulfoxide（最終濃度 2\%）で溶解した。 コルヒチ ン処理は， 4 種類の濃度 $(0.001 ， 0.005,0.1$ および $0.2 \%)$
と 10 種類の処理時間 $(0.5 ， 1 ， 2 ， 4 ， 6 ， 12 ， 24 ， 48 ， 72$ および 96 時間）を組み合わせた 20 処理区とした。一方，才 リザリン処理は， 2 種類の濃度（0.001 抢よび $0.005 \%)$ と 3 種類の処理時間（12，24 および 48 時間）を組久合わせた 6 処理区を設けた。なお，いずれの処理区も 30 本のシュー トを供試した。 コルヒチンまたはオリザリン処理後の シュートを, 滅菌水で 3 回洗浄し, $20 \mathrm{~mm}$ ずつに切り分け, 前述した培地上に置床した。培養 2 か月後に，処理した シュートの腋芽から発生したシュートのらち 1 本を無作為 に選び, フローサイトメーター(FCM;EPICS XL, BECKMAN COULTER）で倍数性を解析した。一部改良を加えた Yahata ら (2005a) の方法に従い, 採取した試料 $50 \mathrm{mg}$ に $1 \mathrm{~mL}$ chopping buffer $\left[6.30 \mathrm{~g} \cdot \mathrm{L}^{-1} \mathrm{Na}_{2} \mathrm{SO}_{3}, 10.0 \mathrm{~g} \cdot \mathrm{L}^{-1}\right.$ Triton X-100, $6.06 \mathrm{~g} \cdot$ $\mathrm{L}^{-1}$ トリス塩酸, $10.0 \mu \mathrm{g} \cdot \mathrm{L}^{-1}$ RNase, $50.0 \mathrm{~g} \cdot \mathrm{L}^{-1}$ Polyvinylpyrrolidone (PVP-10), pH 7.5]を加光, シャーレ上で約 100 回 細かく刻久, $20 \mu \mathrm{m}$ Cell Trics filter（Partec）によりろ過した. さらに，測定直前に，ろ液に $50 \mu \mathrm{l}$ の $500 \mathrm{mg} \cdot \mathrm{L}^{-1}$ Propidium iodide 溶液を加兄て混合することで核を蛍光染色し, 相対蛍 光強度別に核をカウントした.

染色体倍加個体と推測されたものを, 山内（佐藤）ら （2012）の方法に従い順化した. すなわち，FCM 解析を行っ たシュートと同位置の腋芽から新たに伸長したシュートを 採取し，ピートモスとボラ土を等量混合したセル成型卜 レー $(20 \times 20 \times$ 深さ $40 \mathrm{~mm} /$ 七ル $)$ に根の無い状態で直接 挿し木した. 挿し木後，七ル成型トレーはプラスチック製 の密閉容器に入れ, $25^{\circ} \mathrm{C}$, 相対湿度 $90 \sim 100 \%, 30 \mu \mathrm{mol}$ ・ $\mathrm{m}^{-2} \cdot \mathrm{s}^{-1}$ の 12 時間照明条件下のインキュベータ内で発根と 順化を同時に行った。

また，順化 $2 \sim 4$ 週間後に，植物体から根端 $0.5 \mathrm{~cm}$ を採 取し，一部修正を加えた Fukui（1996）の方法に従い染色 体を観察した．すなわち，採取した根端を $2 \mathrm{mM} 8$ 8一ドロ キシキノリンで室温, 2 時間前処理後, 固定液 (エタノー ル:酢酸 $=3: 1$ ）で室温，1時間固定した．固定後，根端を 蒸留水で 30 分間水洗して固定液を取り除き，3\%七ルラー ゼ “オノズカ” RS（ヤクルト），2\%マセロザイム R-200（ヤ クルト)，1\%ペクトリアーゼY-23（キッコーマン）拈よび $200 \mathrm{mM}$ EDTA を含む酵素液に $37^{\circ} \mathrm{C}$ で 30 分間浸漬した. 酵 素処理後, 根端をスライドグラス上に移し, 固定液を加え て細胞を拡散させ，室温で乾燥させた後 $2 \%$ ギムザ夜で 30 分間染色し, 水洗後に乾燥させて染色体標本を作成し た. これらの染色体標本について, 光学顕微鏡 (BX-51, OLYMPUS）を用いて染色体数を数えた。なお，順化後の 倍加個体は，ラビットアイブルーベリ一台木に接ぎ木して 育成した。

\section{2. オリザリン処理による日本産野生種の染色体倍加} (実験 2)

ナッハゼ (二倍体)，スノキ(V. smallii A. Gray）(二倍体), コケモモ（V. vitis-idaea L.）（二倍体）拈よびクロマメノキ （六倍体）の腋芽を用いて, 前記と同様の方法で多芽体を誘 
導した.な拈, ナツハゼとクロマメノキは新潟県立植物園, スノキは樹美庵（園芸店）、コヶモモは湯沢園芸（園芸店） より導入した。これらの多芽体から得られたシュートを, 実験 1 と同様の方法でオリザリン処理を行った. 処理条件 は，実験 1 の結果に基づき， $0.005 \% ・ 24$ 時間とし，20〜 90 本のシュートを供試した. 培養 2 か月後に実験 1 と同様 に, 得られたシュートの倍数性を解析し, 発根処理と順化 を同時に行った。 また, 倍数性キメラ個体に関しては, 順
化後に育成して染色体倍加個体を分離した後，ラビットア イブルーベリー台木に接ぎ木した。

\section{結 果}

\section{1. 栽培品種でのコルヒチンおよびオリザリン処理条件の 検討（実験 1)}

コルヒチンとオリザリンを処理したシュートは，無処理 区と比較して発芽が遅く, その傾向は処理濃度の上昇と処

第 1 表 北部ハイブッシュブルーベリー ‘Berkeley’ シュートヘのコルヒチン処理が染色体倍加に及ぼす影響

\begin{tabular}{|c|c|c|c|c|c|c|c|}
\hline \multirow{2}{*}{ 処理濃度（\%) } & \multirow{2}{*}{ 処理時間 } & \multirow{2}{*}{ 供試数 } & \multirow{2}{*}{ 生存シュート数 } & \multirow{2}{*}{ 生存率 ${ }^{\mathrm{y}}$} & \multicolumn{3}{|c|}{ 倍数性 } \\
\hline & & & & & $4 x(\%)^{x}$ & $4 x+8 x \quad(\%)$ & $8 \mathrm{x}(\%)$ \\
\hline 対照区 ${ }^{w}$ & 0 & 30 & 30 & 100 & $30(100)$ & $0(0)$ & $0(0)$ \\
\hline \multirow{5}{*}{0.001} & 12 & 30 & 30 & 100 & $30(100)$ & $0(0)$ & $0(0)$ \\
\hline & 24 & 30 & 30 & 100 & $30(100)$ & $0(0)$ & $0(0)$ \\
\hline & 48 & 30 & 29 & 96.7 & $22(73.3)$ & $6(20.0)$ & $1(3.3)$ \\
\hline & 72 & 30 & 23 & 76.7 & $19(63.3)$ & $2(6.7)$ & $2(6.7)$ \\
\hline & 96 & 30 & 14 & 46.7 & $13(43.3)$ & $1(3.3)$ & $0(0)$ \\
\hline \multirow{5}{*}{0.005} & 12 & 30 & 20 & 66.7 & $15(50.0)$ & $5(16.7)$ & $0(0)$ \\
\hline & 24 & 30 & 28 & 93.3 & $23(76.7)$ & $5(16.7)$ & $0(0)$ \\
\hline & 48 & 30 & 17 & 56.7 & $12(40.0)$ & $4(13.3)$ & $1(3.3)$ \\
\hline & 72 & 30 & 29 & 96.7 & $26(86.7)$ & $2(6.7)$ & $1(3.3)$ \\
\hline & 96 & 30 & 29 & 96.7 & $15 \quad(50.0)$ & $10(33.3)$ & $4(13.3)$ \\
\hline \multirow{5}{*}{0.1} & 0.5 & 30 & 29 & 96.7 & $28(93.3)$ & $1(3.3)$ & $0(0)$ \\
\hline & 1 & 30 & 28 & 93.3 & $27(90.0)$ & $1(3.3)$ & $0(0)$ \\
\hline & 2 & 30 & 28 & 93.3 & $28(93.3)$ & $0(0)$ & $0(0)$ \\
\hline & 4 & 30 & 30 & 100 & $27(90.0)$ & $3(10.0)$ & $0(0)$ \\
\hline & 6 & 30 & 23 & 76.7 & $21(70.0)$ & $2(6.7)$ & $0(0)$ \\
\hline \multirow{5}{*}{0.2} & 0.5 & 30 & 29 & 96.7 & $26(86.7)$ & $2(6.7)$ & $1(3.3)$ \\
\hline & 1 & 30 & 24 & 80.0 & $23(76.7)$ & $0(0)$ & $1(3.3)$ \\
\hline & 2 & 30 & 30 & 100 & $25(83.3)$ & $5(16.7)$ & $0(0)$ \\
\hline & 4 & 30 & 24 & 80.0 & $19(63.3)$ & $4(13.3)$ & $1(3.3)$ \\
\hline & 6 & 30 & 24 & 80.0 & $18(60.0)$ & $4(13.3)$ & $2(6.7)$ \\
\hline
\end{tabular}

zュルヒチン処理後に MW 培地で 2 か月間培養を行い, 各シュートの腋芽から新たに発生したシュートを無作為に 1 本選び，フ ローサイトメーターで倍数性を解析した

$\mathrm{y}$ (生存シュート数 / 供試数 $) \times 100$ により算出した

$\mathrm{x}$ 括弧内は供試数に対する割合を示す

w 調整したシュートを直接 MW 培地に置床して 2 か月間培養し，同様に倍数性を解析した

第 2 表 北部ハイブッシュブルーベリー ‘Berkeley’ シュートヘのオリザリン処理が染色体倍加に及ぼす影響る

\begin{tabular}{|c|c|c|c|c|c|c|c|}
\hline \multirow{2}{*}{ 処理濃度（\%） } & \multirow{2}{*}{ 処理時間 } & \multirow{2}{*}{ 供試数 } & \multirow{2}{*}{ 生存シュート数 } & \multirow{2}{*}{ 生存率 y } & \multicolumn{3}{|c|}{ 倍数性 } \\
\hline & & & & & $4 x(\%)^{x}$ & $4 x+8 x \quad(\%)$ & $8 \mathrm{x}(\%)$ \\
\hline 対照区 ${ }^{w}$ & 0 & 30 & 30 & 100 & $30(100)$ & $0(0)$ & $0(0)$ \\
\hline \multirow{3}{*}{0.001} & 12 & 30 & 30 & 100 & $30(100)$ & $0(0)$ & $0(0)$ \\
\hline & 24 & 30 & 30 & 100 & $23(76.7)$ & $7(23.3)$ & $0(0)$ \\
\hline & 48 & 30 & 26 & 86.7 & $22(73.3)$ & $3(10.0)$ & $1(3.3)$ \\
\hline \multirow{3}{*}{0.005} & 12 & 30 & 27 & 90.0 & $18(60.0)$ & $4(13.3)$ & $4(13.3)$ \\
\hline & 24 & 30 & 24 & 80.0 & $16(53.3)$ & $1(3.3)$ & $7(23.3)$ \\
\hline & 48 & 30 & 1 & 3.3 & $1(3.3)$ & $0(0)$ & $0(0)$ \\
\hline
\end{tabular}

zオリザリン処理後に MW 培地で 2 か月間培養を行い, 各シュートの腋芽から新たに発生したシュートを無作為に 1 本選び，フ ローサイトメーターで倍数性を解析した

$\mathrm{y}$ (生存シュート数／供試数) $\times 100$ により算出した

$\mathrm{x}$ 括弧内は供試数に対する割合を示す

w調整したシュートを直接 MW 培地に置床して 2 か月間培養し, 同様に倍数性を解析した 


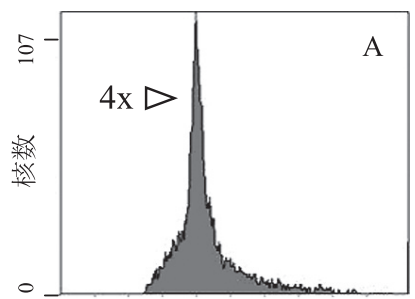

相対蛍光強度

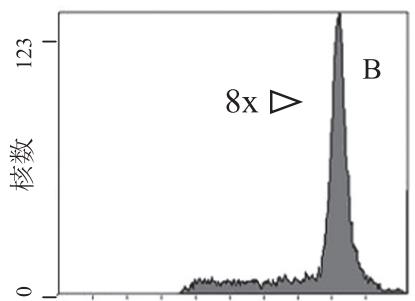

相対蛍光強度



相対蛍光強度

第 1 図コルヒチン処理した北部ハイブッシュブルーベリー ‘Berkeley’ の多芽体由来シュートから新たに発生した シュートのフローサイトメーターによる倍数性解析 $\mathrm{A}$ ：四倍体，B：八倍体， C : 倍数性キメラ（四倍体と 八倍体）

理時間の延長により，さらに強くなった。 しかし，処理 2 か月後には個体数に差異があるものの，すべての処理区で シュートが得られた.

コルヒチン処理試験の結果 (第 1 表)， $0.001 \%$ の 12 招よ び 24 時間処理ではすべてのシュートが生存していたが, 48 時間以上の処理区では処理時間が長くなるにつれて生存率 が減少し，96 時間処理では 46.7\%であった． $0.005 ， 0.1$ お よび $0.2 \%$ では, 処理時間がシュートの生存率に及ぼす影響
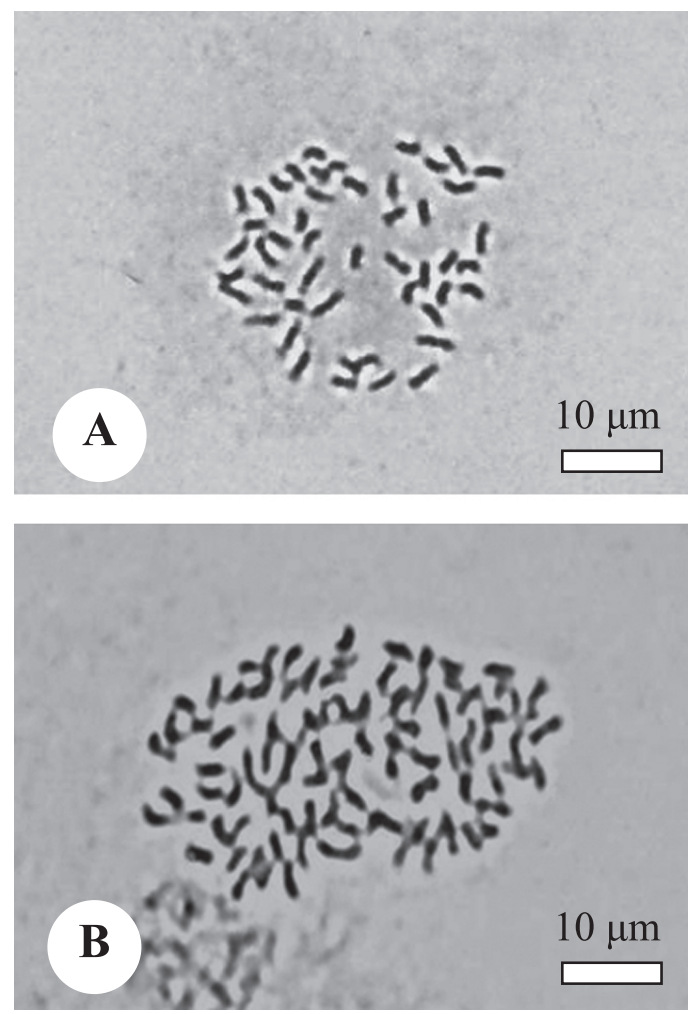

第 2 図 北部ハイブッシュブルーベリー 'Berkeley' $(2 \mathrm{n}=4 \mathrm{x}=$ 48）(A）とシュートへのコルヒチン処理から得られた 八倍体 $(2 \mathrm{n}=8 \mathrm{x}=96) （ \mathrm{~B})$ の根端の染色体

に一定の傾向は見られなかった. 生存シュートの FCM 解 析を行った結果（第 1 図 $\mathrm{A} \sim \mathrm{C}$ )，四倍体，八倍体拈よび倍 数性キメラ（四倍体と八倍体）が認められた． $0.001 \%$ の 12 および 24 時間処理では, すべてのシュートが四倍性を示し た.しかし，48 時間区では $20.0 \%$ の倍数性キメラが誘導さ れ, 72 時間区では $6.7 \%$ のシートが八倍体であった. 0.005 \%のすべての処理区で倍数性キメラ $(6.7 \sim 33.3 \%)$ が得ら れた。 それに対し，八倍体は48 時間以上の処理区で得ら れ，96 時間が 13.3\% と最も高い染色体倍加個体誘導率を示 した. $0.1 \%$ 区では，4 時間処理で $10.0 \%$ の倍数性キメラが 得られたものの, 染色体倍加個体は全く誘導できなかった. $0.2 \%$ 区では，2 時間処理以外で染色体倍加個体が得られた

第 3 表 我が国自生スノキ属植物シュートヘのオリザリン処理が染色体倍加に及ぼす影響

\begin{tabular}{|c|c|c|c|c|c|c|c|c|c|}
\hline \multirow{2}{*}{ 供試個体 } & \multirow{2}{*}{ 供試数 } & \multirow{2}{*}{$\begin{array}{c}\text { 生存 } \\
\text { シュート数 }\end{array}$} & \multirow{2}{*}{ 生存率 $\mathrm{y}$} & \multicolumn{6}{|c|}{ 倍数性 } \\
\hline & & & & $2 \mathrm{x}[6 \mathrm{x}]$ & $(\%)^{x}$ & $2 x+4 x \quad[6 x+12 x]$ & $(\%)$ & $4 \mathrm{x}[12 \mathrm{x}]$ & $(\%)$ \\
\hline ナツハゼ & 30 & 26 & 86.7 & 23 & $(76.7)$ & 3 & $(10.0)$ & 0 & $(0)$ \\
\hline スノキ & 90 & 82 & 91.1 & 44 & $(48.9)$ & 33 & $(36.7)$ & 5 & $(5.6)$ \\
\hline コケモモ & 20 & 16 & 80.0 & 0 & $(0)$ & 8 & $(40.0)$ & 8 & $(40.0)$ \\
\hline クロマメノキ w & 90 & 90 & 100 & {$[21]$} & $(23.3)$ & {$[17]$} & (18.9) & 52 & $(57.8)$ \\
\hline
\end{tabular}

zシュートを $0.005 \%$ のオリザリン溶液に 24 時間浸漬後, MW 培地で 2 か月間培養を行い，各シュートの腋芽から新たに発生し たシュートを無作為に 1 本選抜しフローサイトメーターで倍数性を解析した

$\mathrm{y}($ 生存シュート数／供試数 $) \times 100$ により算出した

$\mathrm{x}$ 括弧内は供試数に対する割合を示す

wクロマメノキは六倍体のため, $6 \mathrm{x}, 6 \mathrm{x}+12 \mathrm{x}$ 抢よび $12 \mathrm{x}$ を示した 

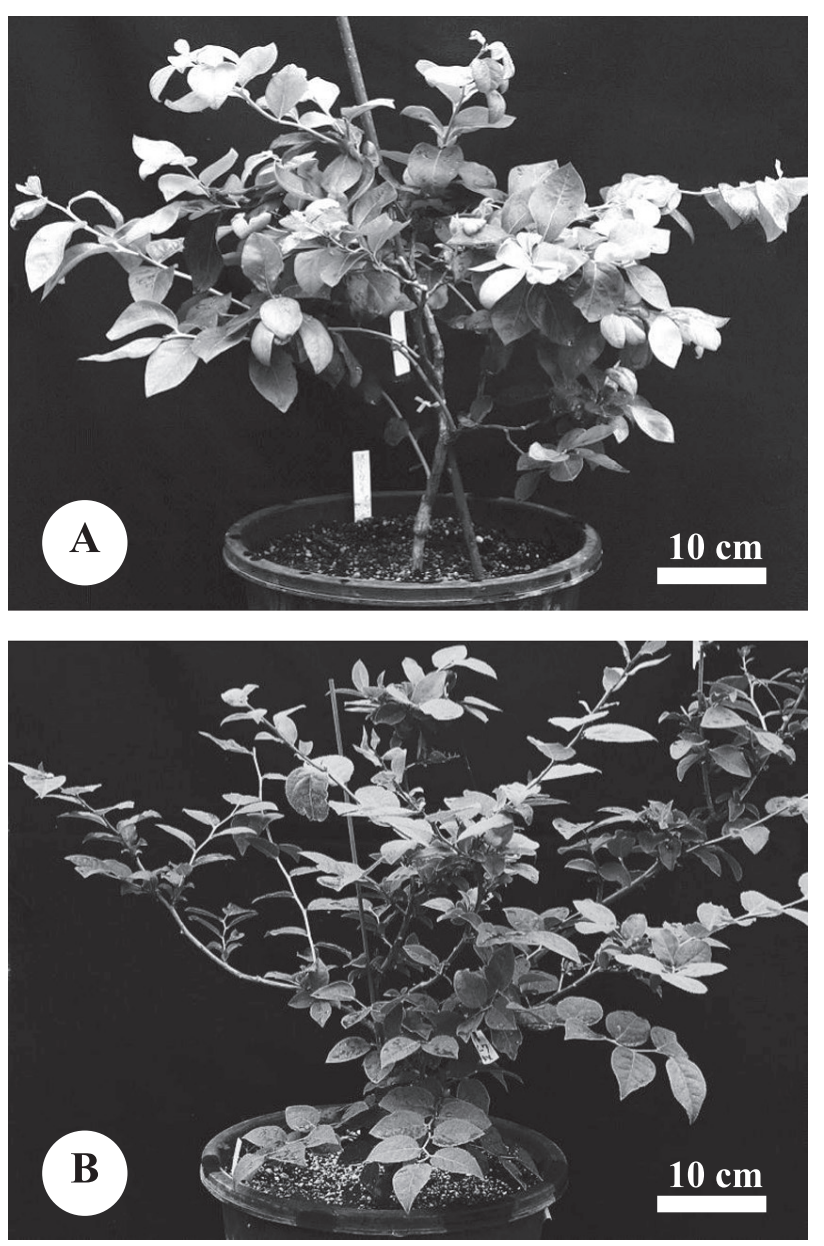

第 3 図オリザリン処理から得られた染色体倍加個体の接ぎ 木 2 年後の様子

A : 'Berkeley’ (八倍体), B : ナッハゼ（四倍体）

が，その誘導率は 6 時間処理の $6.7 \%$ が最高であった。

オリザリン処理を行った結果（第 2 表），0.001\%区の生 存率は 12,24 および 48 時間処理区において, それぞれ 100，100 および 86.7\%であった. 一方，0.005\%区では， 12 および 24 時間区が 90.0 および $80.0 \%$ の生存率であったの に対し，48 時間区では $3.3 \%$ と非常に低い生存率であった.
0.001\%区では，染色体倍加個体が 48 時間区の 1 個体（3.3 \%)のみであった。しかし，0.005\%区では，12 および 24 時間処理でそれぞれ 13.3 打よび $23.3 \%$ の染色体倍加個体が 得られた.

FCM 解析によって八倍体と推測された個体を順化し, 四 倍体とともに根端の染色体数を観察した結果, それぞれ 96 および48本の染色体数を有する八倍体と四倍体であること が確認され，FCM 解析の結果と一致した（第 2 図）。コル ヒチン処理によって得られた八倍体は，接ぎ木後 2 年を経 過しても順調な生育を示している（第3 図 A).

以上の結果，スノキ属植物に拈いては， $0.005 \% ・ 24$ 時間 のオリザリン処理を行うことにより，効率的に染色体倍加 個体を誘導できるものと思われた。

\section{2. オリザリン処理による日本産野生種の染色体倍加} (実験 2)

$0.005 \%$ ・24 時間の条件で，日本産野生種 4 種にオリザリ ン処理を行った結果，生存率は $80.0 \sim 100 \%$ であり，種間 による差異が認められた(第 3 表). FCM で得られたシュー トを解析したところ，種によって染色体倍加個体の誘導率 が異なった。すすおち，スノキでは四倍体誘導率が $5.6 \%$ で，倍数性キメラ（二倍体と四倍体）誘導率が $36.7 \%$ であ り，倍数性キメラの方が多かった．コケモモでは，四倍体 と倍数性キメラ (二倍体と四倍体)の誘導率がいずれも 40.0 \%となった，クロマメノキでは，57.8\%といら高率で十二 倍体が得られた. 順化した染色体倍加個体の根端の染色体 数を調査したところ，FCM で四倍体と推定されたスノキ （第 4 図）とコケモモは 48 本の染色体を有する四倍体であ ることが確認されたが，クロマメノキは正確な染色体数を 確認するには至らなかった，ナッハゼは，四倍体が得られ ず倍数性キメラ（二倍体と四倍体）の誘導率も10\%であっ たが，順化後に完全な染色体倍加個体を分離し，ラビット アイブルーベリー台木に接ぎ木し，順調な生育を示してい る(第 3 図 B).

考 察
スノキ属では, ラビットアイブルーベリー, ハイブッシュ
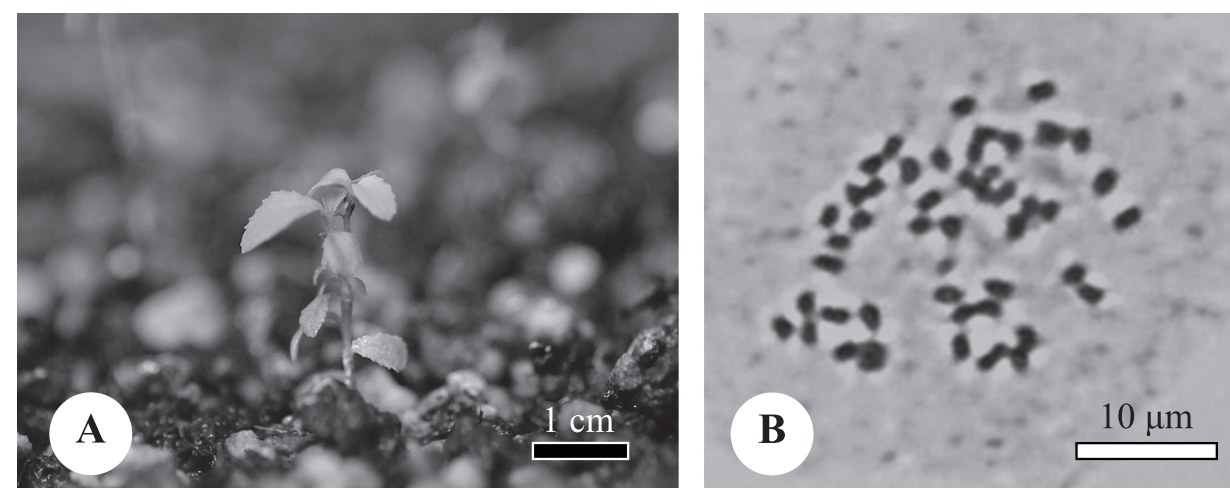

第 4 図 シュートへのオリザリン処理から得られた四倍体スノキ（A）と根端の染色体（2n= $4 \mathrm{x}=48 ）(B)$ 
ブルーベリー拈よびそれらと野生種との交雑種などで，コ ルヒチン処理による染色体倍加が試みられている (Dweikat・ Lyrene, 1989; Goldy•Lyrene, 1984; Lyrene • Perry, 1982; Perry・ Lyrene, 1984）. これらの研究におけるコルヒチン処理濃度 は $0 \sim 0.2 \%$, 処理時間は 6 時間〜 8 週間と多様である. Lyrene・Perry（1982）は，コルヒチン処理したシュートで は生存率の減少と生育の抑制が認められ，処理後にコルヒ チン無添加培地で培養したシュートの中には，伸長開始ま で数か月を要したことを報告している. また, Perry・Lyrene （1984）は，コルヒチンを処理した 3 種すべてで，コルヒチ ン濃度の上昇と処理時間の延長によりシュートの生存率が 減少する傾向が認められたが，一部では処理時間と生存率 に関連性がなかったと報告している。本研究においても， コルヒチン処理濃度と時間が生存率に及ぼす影響には, 一 定の傾向が認められなかった，これらのことから，スノキ 属植物のコルヒチンへの反応は, 処理条件, 遺伝子型拉よ び供試部位などにより異なるものと推察された.

オリザリン処理では，処理時間の延長（Allum ら，2007; Dunn・Lindstrom, 2007; Kermani ら, 2003) と濃度の上昇 (van Duren ら，1996）により，供試材料の生存率が減少するこ とが報告されている. 本研究に掞いても, オリザリン処理 した ‘Berkeley’ の生存率は, 処理濃度の上昇と処理時間 の延長により減少した。特に，0.005\%・48 時間では 3.3\% の生存率を示し, 同条件のコルヒチン処理の生存率 (56.7 \%）と比較すると低い值となった．以上のことから，ス～ キ属に打けるオリザリン処理は, コルヒチンと同様に処理 濃度の上昇または処理時間の延長により生存率を低下させ るものと思われたが, 特に, 長時間の処理は植物体へ悪影 響を及洔すものと推察された。

Goldy・Lyrene（1984）は，コルヒチンを添加した液体培 地にハイブッシュブルーベリーのシュートを浸漬処理した 結果, $0.025 \%$ で $24 〜 48$ 時間処理することにより染色体倍 加個体を獲得している. Perry・Lyrene（1984）は, V. elliottii Chapm. のシュートに0.01\%コルヒチンを2週間処理するこ とにより染色体倍加個体を獲得したが，コルヒチンへの反 応は遺伝子型により異なったと報告している. Dweikat・ Lyrene (1989) は，ハイブッシュブルーベリーとV. elliottii Chapm. の三倍体種間雑種 FL 81-19 のシュートを，0.02\% ルヒチン添加培地で 6 日間培養することにより, 最も高い 頻度で染色体倍加個体を獲得している。しかしながら，こ れらの報告では，染色体倍加個体の誘導率には全く言及さ れていない。本研究では, 'Berkeley’に打いて濃度と時間 を組久合わせた 20 のコルヒチン処理区のうち, 10 処理区 で染色体倍加個体が得られ，このらち $0.005 \%$ の 96 時間処 理区では，13.3\%の染色体倍加個体誘導率を示した。

van Duren ら（1996）は，バナナのシュートにコルヒチン とオリザリンを処理し，コルヒチン処理 $(0.2 \% ・ 48$ 時間 $)$ の染色体倍加個体誘導率が最高 23.1\%であったのに対し， オリザリン処理 $(0.01 \% ・ 7$ 日間) のそれは最高 $29.1 \%$ を示
し，オリザリン処理に拈いて染色体倍加個体誘導率が高 かったとしている.リンゴ（Bouvier ら，1994）やキウイフ ルーツ（Chalak・Legave, 1996）でも，コルヒチン処理に比 ベてオリザリン処理で四倍体の誘導率が高いことが報告さ れている. 本研究においても, ‘Berkeley’のオリザリン処 理による染色体倍加個体誘導率の最高は 23.3\%（0.005\%・ 24 時間）であり，コルヒチン処理（13.3\%）よりも高い值 を示した. 日本産野生種 3 種においても，5.6～57.8\%の割 合で染色体倍加個体を獲得し，倍数性キメラ個体から分離 した染色体倍加個体を含めると，オリザリン処理により， 日本産スノキ属植物すべての染色体倍加個体を獲得するこ とに成功した。

以上の結果，スノキ属の染色体倍加に及ぼすオリザリン 処理の有効性が明らかとなった. 本研究で得られた染色体 倍加個体は，ラビットアイブルーベリ一台木に接ぎ木した 後, 順調な生育を示している. カンキッにおいては，コル ヒチン処理によって得られた染色体倍加個体は，完全にす べての細胞が倍加していない場合，育成中に元の倍数体に 戻ることや周縁キメラになることが報告されていることか ら（古田ら，2004; 糠谷ら，2011; Yahata ら，2005b），今後 は，生育特性や生殖稔性を調査するとともに，染色体倍加 した日本産野生種の倍数性の再解析を行う必要があると考 えられる。

\section{摘 要}

我が国に自生するスノキ属植物とブルーベリ一栽培品種 に打いて，多芽体由来シュートを用いた染色体倍加を検討 した。オリザリンとコルヒチンを様々な濃度や時間で シュートに処理し，その後 $5 \mathrm{mg} ・ \mathrm{~L}^{-1}$ zeatin を添加した $\mathrm{MW}$ 培地で培養した。培養したシュートの腋芽から新たに発生 したシュートの倍数性を解析した. 染色体倍加個体の誘導 率は有系分裂阻害物質の種類，処理濃度，処理時間拈よび 供試した種により異なったが，本処理条件内では，オリザ リンの方がコルヒチンより高い值を示した．特に，0.005 $\%$ ・24 時間でオリザリン処理を行った場合, 北部ハイブッ シュブルーベリー 'Berkeley'，スノキ，コケモモおよびク ロマメノキに打いて 23.3，5.6，40.0 抢よび57.8\%の染色体 倍加個体が得られた。 これらの染色体倍加個体は，ラビッ トアイブルーベリ一台木に接ぎ木した後，順調な生育を示 している. 以上のように，多芽体由来シュートへのオリザ リン処理により，スノキ属植物の染色体倍加個体を効率的 に誘導できることが明らかになった.

\section{引用文献}

Allum, J. F., D. H. Bringloe and A. V. Roberts. 2007. Chromosome doubling in a Rosa rugosa Thunb. hybrid by exposure of in vitro nodes to oryzalin: the effects of node length, oryzalin concentration and exposure time. Plant Cell Rep. 26: $1977-1984$. 
Blakeslee, A. F. and A. G. Avery. 1937. Methods of inducing doubling of chromosomes in plants. J. Hered. 28: 393-411.

Bouvier, L., F. R. Fillon and Y. Lespinasse. 1994. Oryzalin as an efficient agent for chromosome doubling of haploid apple shoots in vitro. Plant Breed. 113: 343-346.

Bouvier, L., P. Guerif, M. Djulbic, C. Durel, E. Chevreau and Y. Lespinasse. 2002. Chorosome doubling of pear haploid plants and homozygosity assessment using isozyme and microsatellite markers. Euphytica 123: 255-262.

Chalak, L. and J. M. Legave. 1996. Oryzalin combined with adventitious regeneration for an efficient chromosome doubling of trihaploid kiwifruit. Plant Cell Rep. 16: 97-100.

Chavez, D. J. and P. M. Lyrene. 2009a. Interspecific crosses and backcrosses between diploid Vaccinium darrowii and tetraploid southern highbush blueberry. J. Amer. Soc. Hort. Sci. 134: 273-280.

Chavez, D. J. and P. M. Lyrene. 2009b. Production and identification of colchicine-derived tetraploid Vaccinium darrowii and its use in breeding. J. Amer. Soc. Hort. Sci. 134: 356363.

Dunn, B. L. and J. T. Lindstrom. 2007. Oryzalin-induced chromosome doubling in Buddleja to facilitate interspecific hybridization. HortScience 42: 1326-1328.

Dweikat, I. M. and P. M. Lyrene. 1989. Production and evaluation of synthetic hexaploid in blueberry. Theor. Appl. Genet. 77: 799-804.

Dweikat, I. M. and P. M. Lyrene. 1991. Induced tetraploidy in a Vaccinium elliottii clone facilitates crossing with cultivated highbush blueberry. J. Amer. Soc. Hort. Sci. 116: 10631066.

Fukui, K. 1996. Plant chromosome at mitosis. p. 1-17. In: K. Fukui and S. Nakayama (eds.). Plant Chromosome. Laboratory Methods. CRC Press, Florida.

古田貴音・金好純子・金石新作・山口 聰. 2004. カンキ ツの処理個体に打ける倍数性の変化と四倍体選抜. 園 学雑. 73 (別 2) : 102.

Goldy, R. G. and P. M. Lyrene. 1984. In vitro colchicine treatment of $4 \mathrm{x}$ bluberries, Vaccinium sp. J. Amer. Soc. Hort. Sci. 109: 336-338.

Hiirsalmi, H. M. 1988. Small fruit breeding in Finland. J. Agric. Sci. Finl. 60: 223-234.

岩垣駛夫. 1984. スノキ属の種について. p. 10-14. 岩垣駛 夫・石川駿二 編著. ブルーベリ一の栽培. 誠文堂新 光社. 東京.

Kalt, W., C. F. Forney, A. Martin and R. L. Prior. 1999. Antioxidant capacity, vitamin $\mathrm{C}$, phenolics, and anthocyanins after fresh storage of small fruits. J. Agric. Food Chem. 47: 4638-4644.

Kermani, M. J., V. Sarasan, A. V. Roberts, K. Yokoya, J.
Wentworth and V. K. Sieber. 2003. Oryzalin-induced chromosome doubling in Rosa and its effect on plant morphology and pollen viability. Theor. Appl. Genet. 107: $1195-1200$

北村四郎・村田 源. 原色日本植物図鑑 木本編 I. 1971. 保育社. 大阪.

小松春喜 - 森田恭代 - 辻 雅水 - 具志堅綾 - 小野正輝 - 井 越敬司・小林弘昌・伊藤保之・鹿毛哲朗・吉岡克則・ 國武久登. 2003. クロマメノキと八イブッシュブルー ベリーの種間雑種の育成. 園学雑. 72 (別2）: 355 .

小松春喜 - 大石 寛・桂川明広 - 山崎裕美 - 小野正輝 増岡智加子 ・鹿毛哲朗・吉岡克則・國武久登. 2006. ク ロマメノキとハイブッシュブルーベリー・ブルークロッ プ との種間雑種の果実特性. 園学雑. 75 (別 2): 494.

Lyrene, P. M. and J. R. Ballington. 1986. Wide hybridization in Vaccinium. HortScience 21: 52-57.

Lyrene, P. M. and J. L. Perry. 1982. Production and selection of blueberry polyploids in vitro. J. Hered. 73 : 377-378.

Miyashita, C., S. Ishikawa and M. Mii. 2009. In vitro induction of the amphiploid in interspecific hybrid of blueberry (Vaccinium corymbosum $\times$ Vaccinium ashei) with colchicine treatment. Sci. Hortic. 122: 375-379.

Moore, J. N., D. H. Scott and H. Dermen. 1964. Development of a decaploid blueberry by colchicine treatment. J. Amer. Soc. Hort. Sci. 84: 274-279.

Murashige, T. and F. Skoog. 1962. A revised medium for rapid growth and bioassay with tobacco tissue cultures. Physiol. Plant. 15: 473-497.

糠谷綱希・太田智宏・安田喜一・八幡昌紀・國武久登・ 小松春喜・新居直祐・向井啓雄・原田 久 - 高木敏彦. 2011. ニンポウキンカン珠心肧へのコルヒチン処理に よって得た倍数体の特性とそれらの三倍体育種への利 用. 園学研. 10: 1-8.

Perry, J. L. and P. M. Lyrene. 1984. In vitro induction of tetraploidy in Vaccinium darrowi, $V$. elliottii, and $V$. darrowi $\times V$. elliottii with colchicine treatment. J. Amer. Soc. Hort. Sci. 109: 4-6.

Rousi, A. 1967. Cytological observations on some species and hybrids of Vaccinium. Zuchter/Gen. Breed. Res. 36: 352359.

Sharp, R. H. and W. B. Sherman. 1971. Breeding blueberries for low chilling requirement. HortScience 6: 145-147.

高木良心 ・津田浩利・浅野陽樹・加藤智美 - 小村美穂 ・柚 木崎千鶴子・黒木義一・平原秀秋・甲斐孝憲・小松春 喜・杉本安寛・國武久登. 2005. ブルーベリーとその 在来野生種の果実に打ける抗酸化活性の評価. 園学雑. 74 (別 2) : 343.

Tetsumura, T., Y. Matsumoto, M. Sato, C. Honsho, K. Yamashita, H. Komatsu, Y. Sugimoto and H. Kunitake. 2008. Evalua- 
tion of basal media for micropropagation of four highbush blueberry cultivars. Sci. Hortic. 119: 72-74.

Väinöolä, A. 2000. Polyploidization and early screening of Rhododendron hybrids. Euphytica 112: 239-244.

van Duren, M., R. Morpurgo, J. Dolezel and R. Afra. 1996. Induction and verification of autotetraploids in diploid banana (Musa acuminata) by in vitro techniques. Euphytica 88: $25-34$.

van Tuyl, J. M., B. Meijer and M. P. van Dien. 1992. The use of oryzalin as an alternative for colchicine in in vitro chromosome doubling of Lilium and Nerine. Acta Hortic. 325: 625-630.

Wolfe, D. E., P. Eck and C. Chin. 1983. Evaluation of seven media for micropropagation of highbush blueberry. HortScience 18: 703-705.

Yahata, M., S. Harusaki, H. Komatsu, K. Takami, H. Kunitake, T. Yabuya, K. Yamashita and P. Toolapong. 2005a. Morphological characterization and molecular verification of a fertile haploid pummelo (Citrus grandis Osbeck). J. Amer. Soc. Hort. Sci. 130: 34-40.
八幡昌紀・柏原夕希子・黒木宏憲 - 國武久登・小松春喜. 2004. ニンポウキンカン種子へのコルヒチン拈びオ リザリン処理が四倍体植物誘導に及ぼす影響. 園学研. 3: $11-16$.

Yahata, M., H. Kunitake, T. Yabuya, K. Yamashita, Y. Kashihara and H. Komatsu. 2005b. Production of a doubled haploid from a haploid pummelo using colchicine treatment of axillary shoot buds. J. Amer. Soc. Hort. Sci. 130: 899-903.

山崎 敬. 1989. ツッジ科. p. 122-156. 佐竹義輔・原 寛・ 亘理俊次・冨成忠夫 編. 日本の野生植物 木本 II. 平凡社. 東京.

山内（佐藤）真希子・津田浩利・荒木啓輔・内田飛香・安 田喜一・鉄村挀哉・小松春喜・國武久登. 2012. 我が 国自生のスノキ属植物とブルーベリ一栽培品種に抢け る植物組織培養と試験管外発根を利用したクローン増 殖. 園学研. 11: 13-19.

Yoshizawa, Y., Y. Fukiya, Y. Izumi, K. Hata. J. Iwashita, N. Murofushi and T. Abe. 2002. Induction of apoptosis with an extract of Actinidia polygama fruit in the promyelocytic leukemia cell line HL-60. J. Health Sci. 48: 303-309. 